\title{
Dating simple flakes: Early Bronze Age flake production technology on the Middle Euphrates Steppe, Syria
}

\author{
Yoshihiro Nishiaki \\ The University Museum, The University of Tokyo, Tokyo 113-0033, Japan. Email: nishiaki@um.u-tokyo.ac.jp
}

\begin{abstract}
:
Aceramic flint scatters, comprising very crude cores or flakes and no formalised tools, are frequently found on the Middle Euphrates steppe of northern Syria. Previous studies suggest that many of them are residues of short-term activities by the nomads or shepherds of the Early Bronze Age. In order to verify this interpretation, a more precise chronological framework needs to be established for the Early Bronze Age lithic industry. This paper analyses stratified flake assemblages of the Early Bronze Age at Tell Ghanem al-Ali, a securely radiocarbon-dated settlement on the Middle Euphrates, and examines which occupation level yields assemblages most similar to those of the steppe. Results demonstrate that the lithic industry of this period underwent significant diachronic changes in terms of core reduction technology. Based on the chronological framework developed at Tell Ghanem al-Ali, the steppe assemblages in question can be assigned to different phases of the Early Bronze Age. This finding will help identify processes at the beginning of the extensive exploitation of the steppe, which is regarded as one of the most important socioeconomic changes that occurred among Early Bronze Age communities of the Middle Euphrates.
\end{abstract}

Keywords: the third millennium Mesopotamia; core reduction technology; the Middle Euphrates; pastoral nomadism

\section{Introduction}

The Early Bronze Age society of the Middle Euphrates in Syria is often depicted as a tribal one. Rather than establishing a powerful political centre, as in Mesopotamia and other regions of the Middle East, this society appears to have maintained distinct tribal features such as ancestor worship, kinship relations, territoriality, and seasonal aggregation, and to have been comprised of multidimensional and fairly autonomous groups (Porter 2002, 2008; Falb et al. 2005; Cooper 2006; Peltenburg 2008; Lyonnet 2009). The society's specificity probably derived from the marginal condition of the regional landscape, which consists of the narrow Euphrates lowlands and the vast steppe, both of which received rainfall that was insufficient for stable farming. In this environmental context, pastoralism must have played a major role in subsistence. Incidentally, cuneiform texts indicate that a distinct nomadic group existed in the region, at least in the Akkadian period of the late third millennium and later (Postgate 1994: 83-87). However, actual evidence of pastoralism, nomads and exploitation of

Published by the School of History, Classics and Archaeology, University of Edinburgh ISSN: 2055-0472. URL: http://journals.ed.ac.uk/lithicstudies/

This work is licensed under a Creative Commons Attribution 2.5 UK: Scotland License. 
the Middle Euphrates steppe hinterland during the Early Bronze Age has been poorly documented. The current literature argues in favour of pastoralism, based on archaeological records from mound sites in the Euphrates Valley alone (e.g. Porter 2008; Cooper 2006; Peltenberg 2007). Archaeological evidence from the steppe itself, which should be directly related to nomadic pastoralists or shepherds, is virtually unknown, except for cemeteries (Falb et al. 2005; Meyer 2010; also see Wilkinson 2004).

In an effort to fill this information gap on exploitation of the steppe, we carried out a series of intensive archaeological surveys on the Middle Euphrates between 2008 and 2011 (Nishiaki et al. 2009, 2011a, 2011b, 2012; Nishiaki \& Abe 2010). The surveyed area is within a $10 \mathrm{~km}$ radius from the Early Bronze Age site of Tell Ghanem al-Ali (Figure 1) that was excavated by a Syro-Japanese mission between 2008 and 2010 (Al-Maqdissi \& Ohnuma 2009, 2010, 2011). The surveys revealed numerous traces of Early Bronze Age steppe exploitation. Besides the cemeteries, whose existence was already known (Kohlmeyer 1984; Falb et al. 2005), a new type of evidence involving numerous flint scatters was discovered (Nishiaki 2010a). The flint scatters always consisted of crude unretouched flakes and amorphous cores distributed in small patches, but no readily datable diagnostic artefacts, such as Canaanean blades and tabular scrapers. Nevertheless, I have concluded elsewhere that many of the flint scatters on the steppe belonged to the Early Bronze Age and later periods (Nishiaki 2010a, 2010b). This conclusion was based on a comparative technological analysis of flake assemblages from the Pottery Neolithic-Late Chalcolithic levels of Tell Kosak Shamali, situated about $80 \mathrm{~km}$ upstream from the study region (Nishiaki 2003), the Early Bronze Age assemblage from Square 1 of Tell Ghanem al-Ali and lithics from the steppe survey. The absence of ceramics, architecture and other features indicated that the scatters represent short-term stops, such as shepherd stations, and that their apparent increase from the Early Bronze Age onward may suggest the beginning of extensive steppe exploitation in this period (Nishiaki 2010b, in press).

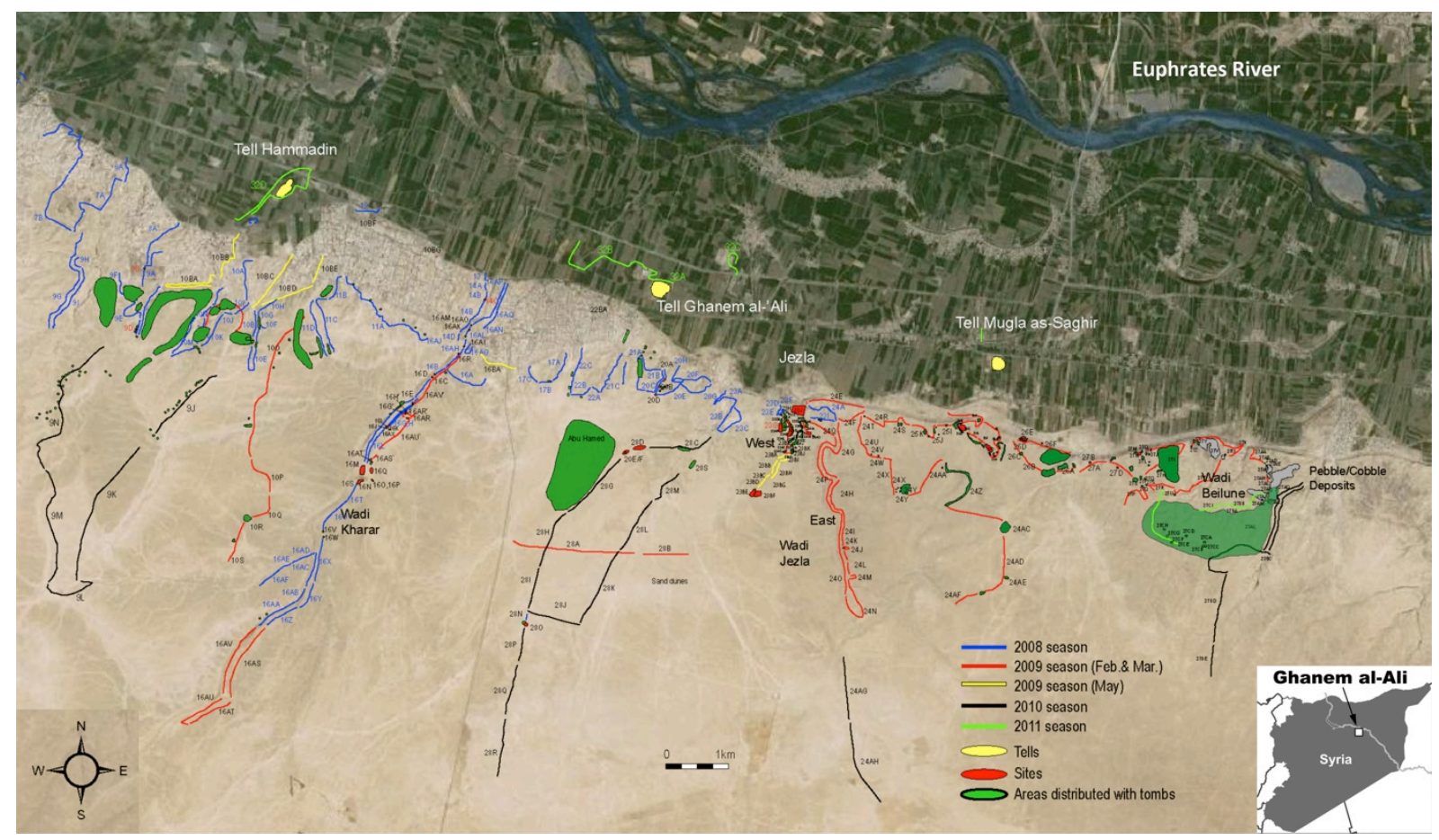

Figure 1. Map showing the location of Tell Ghanem al-Ali and the survey area. The numbers with letters indicate our survey passes. 
In this paper, I will deal with another set of Early Bronze Age lithic assemblages from Square 2 of Tell Ghanem al-Ali in order to test or reinforce the conclusion proposed above. The excavation of Square 2 was recently completed in a deep sounding trench, and the stratified deposits, consisting of eight architectural levels (Hasegawa 2010), have been securely dated with 26 new radiocarbon measurements (Nakamura 2010). Accordingly, a careful analysis of lithic assemblages by level would help us better understand the detailed chronological change of Early Bronze Age flake industries and what phase and corresponding technology of this period are most comparable to the flint scatters on the steppe. The results will help reveal more precisely when exploitation of the steppe became intensive. The analysis would also yield insight on the nature of Early Bronze Age domestic flake production which has rarely received the attention of lithic specialists of this period (Rosen 1997; Hunbury-Tenison 1983; Caneva 1993; Conolly 2003).

\section{The Early Bronze Age site of Tell Ghanem Al-Ali}

Tell Ghanem al-Ali is situated on the right bank of the Middle Euphrates, approximately $50 \mathrm{~km}$ east of Raqqa (Figure 1). The region, which receives fewer than $200 \mathrm{~mm}$ in annual precipitation, encompasses two distinctly different environmental settings. One is a low Holocene terrace of the Euphrates, facing extensive green lowlands that are used for irrigated crop cultivation today, and the other is the barren steppe plateau with limited vegetation, extending further inland, which is currently utilised for livestock herding. The boundary between them is marked by a rather steep cliff of the plateau, approximately $30 \mathrm{~m}$ higher than the lowlands. Along this is a narrow, low terrace on which the modern village of Tell Ghanem al-Ali is situated. The mound is located on the lowlands about $300 \mathrm{~m}$ from the plateau. It occupies an area of about $300 \times 250 \mathrm{~m}$, with a height of $10 \mathrm{~m}$ above the surrounding field. Square 2, the focus of this paper, is one of the eight areas excavated at this mound thus far (Al-Maqdissi and Ohnuma 2009, 2010, 2011). Situated on its northern slope, this square actually consisted of a long step-trench $4 \mathrm{~m}$ wide and $27 \mathrm{~m}$ long, in which eight architectural levels were revealed in deposits approximately $8 \mathrm{~m}$ thick. Being the only area exposed down to virgin soil, it yielded the longest sequence of lithic assemblages.

According to the architectural features, eight levels belonging to the Early Bronze Age have been grouped into three phases (Hasegawa 2010). The oldest Phase 1 (Levels 7 and 8) contained rectangular buildings made of mud bricks, built directly on the ground. In comparison, the mud brick architecture of Phase 2 (Levels 5 and 6) was built with gypsum stones at the base. This building method continued into Phase 3 (Levels 1-4), but the main axis of the walls changed. The longer axis was laid almost in a north-south direction, while that of the earlier two phases was oriented north-west and south-east. Moreover, the massive stone wall was probably built as a town wall in Level 4, and the common use of gypsum plaster for the room floors also distinguishes this phase from the preceding ones.

In addition to these phases defined by the excavators, I suggest another which has been reported as the "topsoil". Varying in thickness up to $1.5 \mathrm{~m}$, this layer contained no evidence of standing architecture, but in contradiction to the conventional meaning of topsoil in the literature-which implies modern mixed contexts containing different archaeological materials - it may represent another occupational phase, in which buildings did not exist, at least based on this limited excavation area. Remarkably, all six radiocarbon dates from the "topsoil" indicate a single period, ca. 2350-2050 cal BCE (Nakamura 2010). I believe that the assemblage deserves to be treated separately. Accordingly, this deposit is designated as Phase 4 here, which may mark the end of the Early Bronze Age occupation at Tell Ghanem al-Ali. 
Based on 26 radiocarbon dates obtained from eight levels and the topsoil (Nakamura 2010; Kume \& Sudo 2010), the dates of these architectural phases can be estimated as follows:
Phase 4 (“topsoil”):
ca. 2350-2050 cal BCE
Phase 3 (Levels 1-4):
ca. 2650-2350 cal BCE
Phase 2 (Levels 6 and 5):
ca. 2900-2650 cal BCE
Phase 1 (Levels 7 and 8):
ca. 3100-2900 cal BCE

As such, the material from this square covers almost the entire third millennium BCE. Following the current chronological scheme developed for the Middle Euphrates region (Lebeau \& de Miroschedji 2011; Porter 2007), Phase 1 roughly corresponds to Early Middle Euphrates 1 (EME 1), Phase 2 to EME 2, Phase 3 to EME 3/4 and Phase 4 to EME 5. In another scheme defined for the nearby Upper Euphrates (Algaze 1999), Phases 1 and 2 are comparable to the early Early Bronze Age (EBA), Phase 3 to the mid-late EBA and Phase 4 to the late EBA and the EBA-MBA transition.

\section{Stratigraphic change of flake production technology at Tell Ghanem Al-Ali}

The most remarkable technological aspect of flint assemblages from the Middle Euphrates steppe is the frequent use of a cortical surface as a striking platform for the cores (Nishiaki 2010b). In other words, striking platforms were rarely prepared before flake production. Core reduction was carried out either on the same working surface as its peripheral cortical edge or on a new working surface on which flake removals were conducted using yet another cortex-covered surface as a platform. This particular technology produced abundant naturally-backed flakes with a thick profile that were utilised almost without subsequent retouch. My previous paper (Nishiaki 2010b) suggested that steppe assemblages with this technology, named Shaboutian after the typical flint scatter site Shabout East on the steppe (Figures 2 and 3), became popular in the Early Bronze Age and later. The purpose of the following analysis is to further specify its chronological position with reference to the stratified data from Square 2 of Tell Ghanem al-Ali.

The flint collection from Square 2 consists of 348 specimens (Table 1). It includes six pieces of heavily-patinated Palaeolithic artefacts which could have been brought in as raw materials (Nishiaki \& Abe 2010: 126) or simply derived from prospecting by the Bronze Age inhabitants. The remaining items are Bronze Age flint artefacts made of local and non-local flints. The significantly more abundant local flints are represented by round, water-rolled cobbles with a brown cortex and bluish-grey interior. Their sizes are principally 5-10 cm in diameter, but a small number of larger ones are also present. Those cobbles are abundantly available in fluvial gravel deposits of the ancient Euphrates, the nearest of which is just a few hundred metres south of the site on the eroded edge of the low terrace along the plateau. Virtually indistinguishable flint cobbles are also available at even higher terraces of the Euphrates on the plateau itself. The most extensive sources, derived from lower Pleistocene gravel deposits (Westaway et al. 2007), are known near Wadi Beilune, about $10 \mathrm{~km}$ east of the site (Figure 1).

Among the non-local raw materials in the collection are flints available at sources in the Bishri Mountains, approximately $40 \mathrm{~km}$ to the south of Tell Ghanem al-Ali. They are very fine-grained and chocolate-brown or black in colour, with fresh cortex present. Banded creamy-brown flints, most likely from southeast Turkey (see Behm-Blancke 1992; Schmidt 1996; Hertenberger et al. 2000; Nishiaki 2012) were also imported. They occurred as segments of a wide, standardised tool type known as Canaanean blades, obviously imported in the form of finished products. 


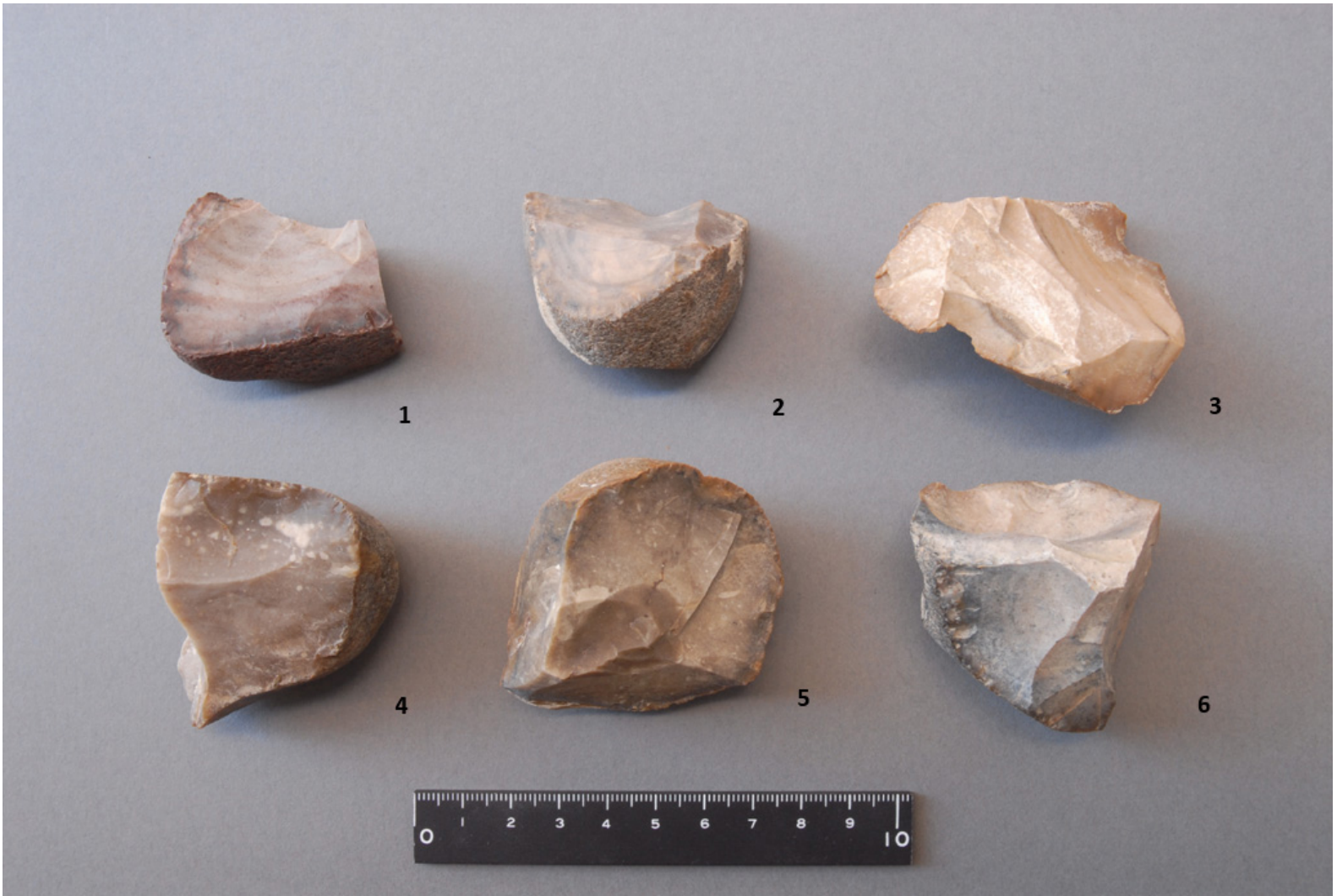

Figure 2. Cores from a flint scatter at Shabout East (Loc. 20A).

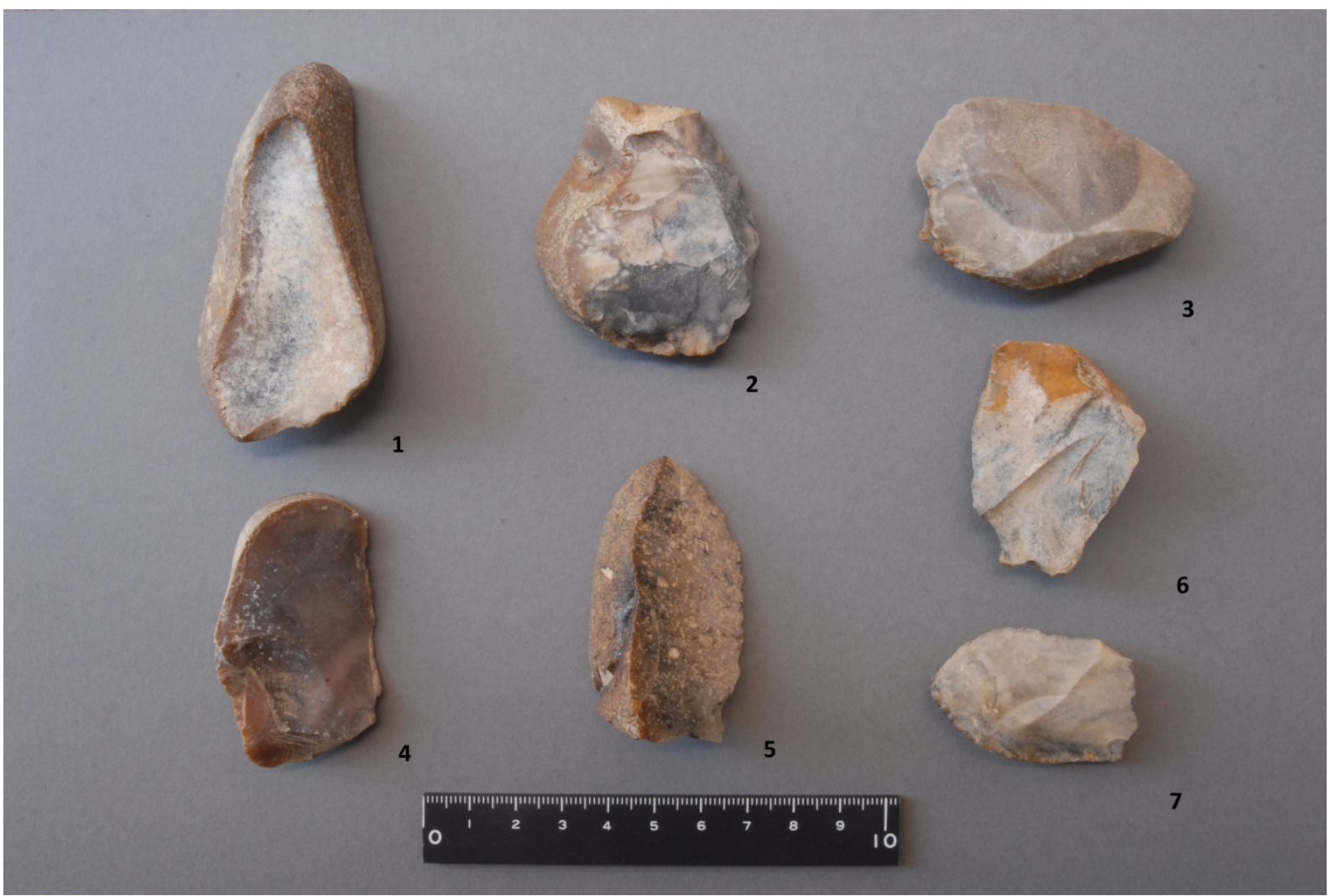

Figure 3. Flakes from a flint scatter at Shabout East (Loc. 20A). Nos. 4 and 7 are retouched. 
Table 1. The flint collection from Square 2 of Tell Ghanem al-Ali.

\begin{tabular}{lcccccccc}
\hline Major categories & Topsoil & Levels 1-3 & Level 4 & Level 5 & Level 6 & Level 7 & Level 8 & Total \\
\hline (Local flint) & & & & & & & & \\
Flint pebbles & $0(0.0)$ & $1(1.2)$ & $0(0.0)$ & $1(1.5)$ & $1(2.2)$ & $0(0.0)$ & $0(0.0)$ & $3(0.9)$ \\
Cores & $9(22.5)$ & $5(6.0)$ & $5(14.3)$ & $10(15.2)$ & $9(19.6)$ & $9(21.4)$ & $7(19.4)$ & $54(15.5)$ \\
Debitage & $26(65.0)$ & $66(79.5)$ & $27(77.1)$ & $50(75.8)$ & $28(60.9)$ & $23(54.8)$ & $24(66.7)$ & $244(70.1)$ \\
Flake tools & $2(5.0)$ & $6(7.2)$ & $3(8.6)$ & $4(6.1)$ & $8(17.4)$ & $5(11.9)$ & $2(5.6)$ & $30(8.6)$ \\
\hline Imported flint) & & & & & & & & \\
Bishri flints & $1(2.5)$ & $2(2.4)$ & $0(0.0)$ & $1(1.5)$ & $0(0.0)$ & $2(4.8)$ & $1(2.8)$ & $7(2.0)$ \\
Canaanean blades & $2(5.0)$ & $0(0.0)$ & $0(0.0)$ & $0(0.0)$ & $0(0.0)$ & $0(0.0)$ & $2(5.6)$ & $4(1.1)$ \\
\hline (Derived pieces) & & & & & & & & \\
Palaeolithic pieces & $0(0.0)$ & $3(3.6)$ & $0(0.0)$ & $0(0.0)$ & $0(0.0)$ & $3(7.1)$ & $0(0.0)$ & $6(1.7)$ \\
\hline Total & $40(100.0)$ & $83(100.0)$ & $35(100.0)$ & $66(100.0)$ & $46(100.0)$ & $42(100.0)$ & $36(100.0)$ & $348(100.0)$ \\
\hline
\end{tabular}

These three raw material groups are easily distinguished through an examination with the naked eye. Artefacts made on local flints will be analysed to examine the local flake production technology. Table 2 shows a classification of the four major core types for the Tell Ghanem al-Ali assemblages. First, cortex-platform cores denote the same type typically occurring on the steppe (see above). Flakes were always detached from a cortex-covered surface, irrelevant to the number of working surfaces (Figure 4: 1-3). Second, workingsurface platform cores represent those with more than one working surface, and the detachment of flakes from the second or subsequent working surface was done using a previous working surface as its striking platform. The cores usually take a globular form (Figure 4: 4-6). The third major type is single-platform cores which have a single striking platform prepared by one or two large flake removals (Figure 4: 7-8). The remaining type is on-flake cores made on thick flake blanks, with minimum preparation before detaching flakes. They resemble single-platform cores, since the ventral surface of the blank was often used as a striking platform (Figure 4: 9).

Table 2. Technological types for cores from Square 2 of Tell Ghanem al-Ali. Abbreviations: w.s.: working surface.

\begin{tabular}{lcccccccc}
\hline Major core types & Topsoil & Levels 1-3 & Level 4 & Level 5 & Level 6 & Level 7 & Level 8 & Total \\
\hline Core splits & $0(0.0)$ & $0(0.0)$ & $0(0.0)$ & $2(20.0)$ & $0(0.0)$ & $1(11.1)$ & $0(0.0)$ & $3(5.6)$ \\
Semi-flaked cores & $0(0.0)$ & $0(0.0)$ & $2(40.0)$ & $1(10.0)$ & $0(0.0)$ & $4(44.4)$ & $1(14.3)$ & $8(14.8)$ \\
$\quad$ Cortex-platform cores & & & & & & & \\
$\quad$ One w.s.* & $5(55.6)$ & $2(40.0)$ & $1(20.0)$ & $1(10.0)$ & $3(33.3)$ & $1(11.1)$ & $0(0.0)$ & $13(24.1)$ \\
Two w.s. & $2(22.2)$ & $0(0.0)$ & $1(20.0)$ & $0(0.0)$ & $0(0.0)$ & $0(0.0)$ & $0(0.0)$ & $3(5.6)$ \\
$\quad$ Three w.s. & $1(11.1)$ & $0(0.0)$ & $0(0.0)$ & $0(0.0)$ & $1(11.1)$ & $0(0.0)$ & $0(0.0)$ & $2(3.7)$ \\
Working surface-platform cores & & & & & & & \\
$\quad$ Two w.s. & $1(11.1)$ & $1(20.0)$ & $0(0.0)$ & $2(20.0)$ & $1(11.1)$ & $1(11.1)$ & $0(0.0)$ & $6(11.1)$ \\
$\quad$ Three w.s. & $0(0.0)$ & $1(20.0)$ & $1(20.0)$ & $3(30.0)$ & $1(11.1)$ & $0(0.0)$ & $3(42.9)$ & $9(16.7)$ \\
Single-platform cores & $0(0.0)$ & $0(0.0)$ & $0(0.0)$ & $0(0.0)$ & $2(22.2)$ & $1(11.1)$ & $1(14.3)$ & $4(7.4)$ \\
On-flake cores & $0(0.0)$ & $1(20.0)$ & $0(0.0)$ & $1(10.0)$ & $1(11.1)$ & $1(11.1)$ & $2(28.6)$ & $6(11.1)$ \\
\hline Total & $9(100.0)$ & $5(100.0)$ & $5(100.0)$ & $10(100.0)$ & $9(100.0)$ & $9(100.0)$ & $7(100.0)$ & $54(100.0)$ \\
\hline
\end{tabular}

Because of the relatively small number of cores in each level, the frequency of these core types is compared by phase in Figure 5. Results show that core technology was never uniform in the Early Bronze Age but exhibited significant temporal changes. The cortex-platform cores, characteristic in the steppe assemblages, rapidly increased through the sequence; they became the most common type in Phase 3, and predominate in Phase 4. In the earlier phases, 
working-surface platform cores are the most abundant, and single-platform cores and on-flake cores also account for a certain proportion of the assemblages.
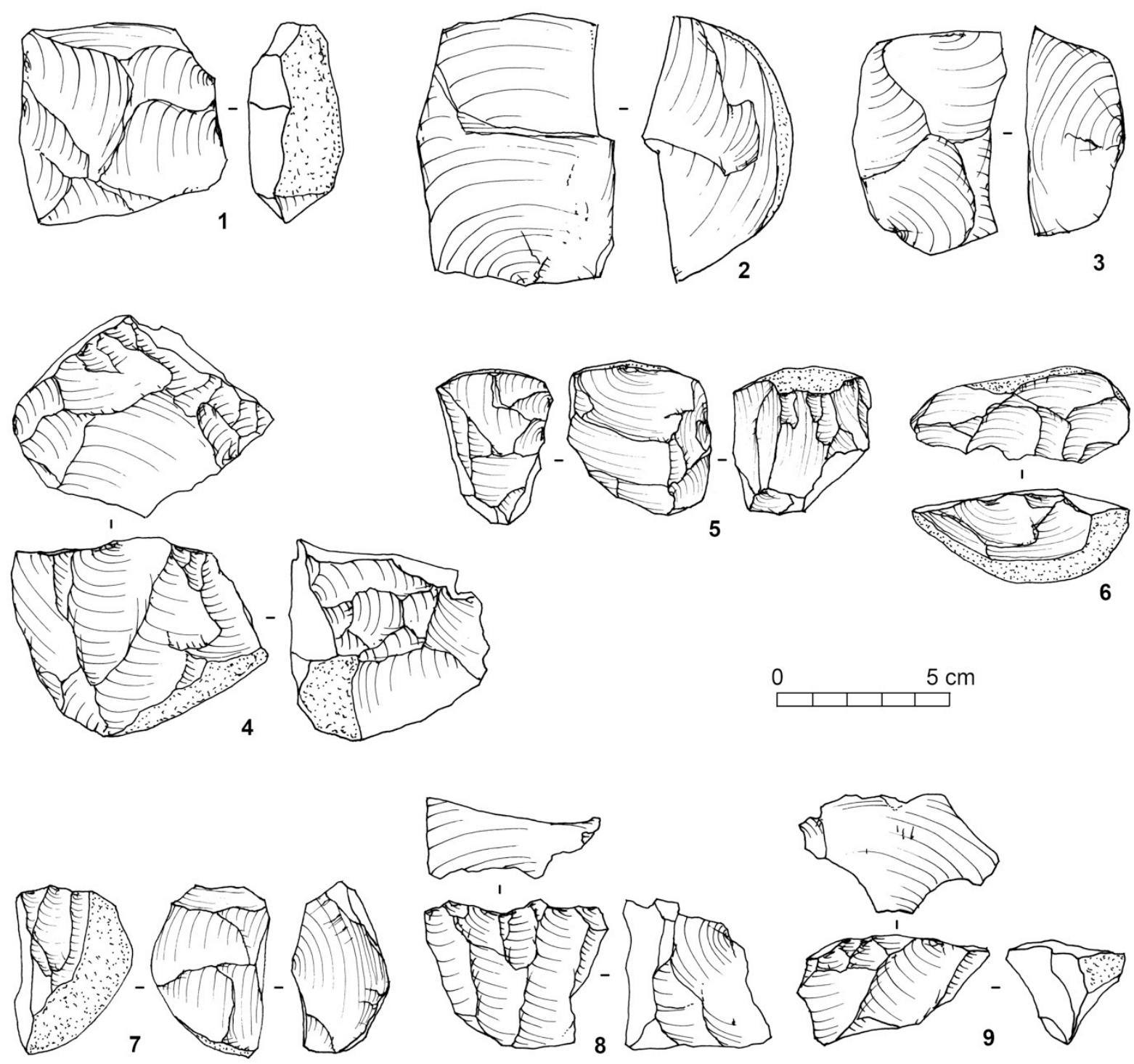

Figure 4. Cores from Square 2 of Tell Ghanem al-Ali. 1-3: cortex-platform cores with one working surface; 4-6: working-surface platform cores; 7-8: single-platform cores; 9: on-flake cores (1, 3 and 4: Level 4; 2: topsoil; 5-7, 9: Level 5; 8: Level 6).

Table 3 summarizes the proportion of general categories in the debitage assemblages. The assemblages include no blade blanks except one partially cortical blade undoubtedly produced by chance. They are also remarkable in that more than 80 to 90 percent of the debitage is cortical (first flakes, cortex flakes and part-cortex flakes) throughout the levels. No change can be detected in this regard, nor did the retouched tools show any temporal changes (Table 4). They were represented by very simple, crude tools, often only referred to as ad hoc tools at best (Figure 6: 3-5). However, the production method for blanks clearly showed a chronological change, as indicated by the breakdown of platform types shown in Table 4. The cortex platform, typical of the steppe assemblages, became very popular in the debitage assemblages from Level 5 on (Figure 6: 1-3), while in the lower levels, a plain or dihedral platform was not uncommon (Figure 6: 4-5). The situation of Level 6 can be regarded as 
intermediate in this diachronic change. In other words, Phase 2 (Levels 5 and 6) seemingly displays a transition. This result is in accordance with that of the aforementioned core analysis. The abundance of flakes with a cortex platform in the upper levels is a direct consequence of using cortex-platform cores, and the higher occurrence of plain or dihedral platforms in the lower levels reflects the common use of working-surface platform cores.

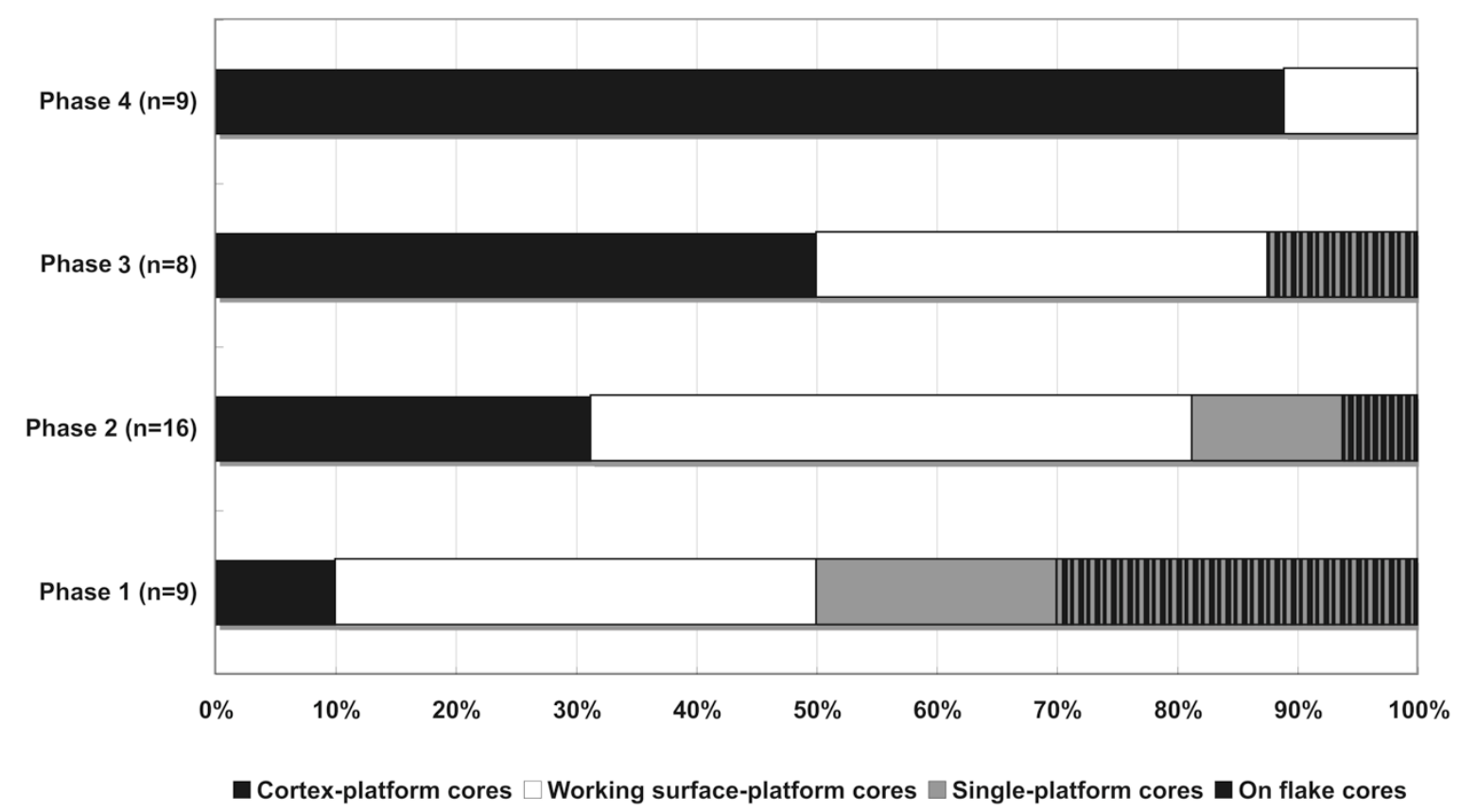

Figure 5. Changes of core types for Tell Ghanem al-Ali by phase.

Table 3. Debitage from Square 2 of Tell Ghanem al-Ali.

\begin{tabular}{lcccccccc}
\hline Major debitage types & Topsoil & Levels 1-3 & Level 4 & Level 5 & Level 6 & Level 7 & Level 8 & Total \\
\hline Core-edge flakes & $0(0.0)$ & $2(3.0)$ & $0(0.0)$ & $2(4.0)$ & $2(7.1)$ & $0(0.0)$ & $0(0.0)$ & $6(2.5)$ \\
First flakes (entames) & $3(11.5)$ & $1(1.5)$ & $1(3.7)$ & $6(12.0)$ & $0(0.0)$ & $2(8.7)$ & $0(0.0)$ & $13(5.3)$ \\
Cortex flakes & $1(3.8)$ & $5(7.6)$ & $0(0.0)$ & $5(10.0)$ & $2(7.1)$ & $7(30.4)$ & $9(37.5)$ & $29(11.9)$ \\
Part-cortex flakes & $18(69.2)$ & $49(74.2)$ & $15(55.6)$ & $25(50.0)$ & $18(64.3)$ & $11(47.8)$ & $12(50.0)$ & $148(60.7)$ \\
Flakes & $2(7.7)$ & $4(6.1)$ & $2(7.4)$ & $3(6.0)$ & $1(3.6)$ & $3(13.0)$ & $1(4.2)$ & $16(6.6)$ \\
Part-cortex blades & $0(0.0)$ & $0(0.0)$ & $0(0.0)$ & $1(2.0)$ & $0(0.0)$ & $0(0.0)$ & $0(0.0)$ & $1(0.4)$ \\
Blades & $0(0.0)$ & $0(0.0)$ & $0(0.0)$ & $0(0.0)$ & $0(0.0)$ & $0(0.0)$ & $0(0.0)$ & $0(0.0)$ \\
Chips \& fragments & $2(7.7)$ & $5(7.6)$ & $9(33.3)$ & $8(16.0)$ & $5(17.9)$ & $0(0.0)$ & $2(8.3)$ & $31(12.7)$ \\
\hline Total & $26(100.0)$ & $66(100.0)$ & $27(100.0)$ & $50(100.0)$ & $28(100.0)$ & $23(100.0)$ & $24(100.0)$ & $244(100.0)$ \\
\hline
\end{tabular}

Table 4. Platform types for debitage products from Square 2 of Tell Ghanem al-Ali.

\begin{tabular}{lcccccccc}
\hline Major platform types & Topsoil & Levels 1-3 & Level 4 & Level 5 & Level 6 & Level 7 & Level 8 & Total \\
\hline Cortical & $16(72.7)$ & $42(80.8)$ & $10(66.7)$ & $34(82.9)$ & $16(57.1)$ & $10(37.0)$ & $10(41.7)$ & $138(66.3)$ \\
Cortical \& Plain & $2(9.1)$ & $1(1.9)$ & $1(6.7)$ & $1(2.4)$ & $1(3.6)$ & $0(0.0)$ & $0(0.0)$ & $6(2.9)$ \\
Plain & $1(4.5)$ & $7(13.5)$ & $2(13.3)$ & $4(9.8)$ & $9(32.1)$ & $15(55.6)$ & $11(45.8)$ & $49(23.6)$ \\
Shattered & $3(13.6)$ & $2(3.8)$ & $2(13.3)$ & $0(0.0)$ & $0(0.0)$ & $0(0.0)$ & $2(8.3)$ & $9(4.3)$ \\
Dihedral & $0(0.0)$ & $0(0.0)$ & $0(0.0)$ & $1(2.4)$ & $2(7.1)$ & $2(7.4)$ & $1(4.2)$ & $6(2.9)$ \\
Faceted & $0(0.0)$ & $0(0.0)$ & $0(0.0)$ & $1(2.4)$ & $0(0.0)$ & $0(0.0)$ & $0(0.0)$ & $1(0.5)$ \\
\hline$\underline{\underline{T}}$ & $\underline{22(100.0)}$ & $\underline{52(100.0)}$ & $\underline{15(100.0)}$ & $\underline{41(100.0)}$ & $\underline{28(100.0)}$ & $\underline{27(100.0)}$ & $\underline{24(100.0)}$ & $\underline{208(100.0)}$ \\
\hline
\end{tabular}



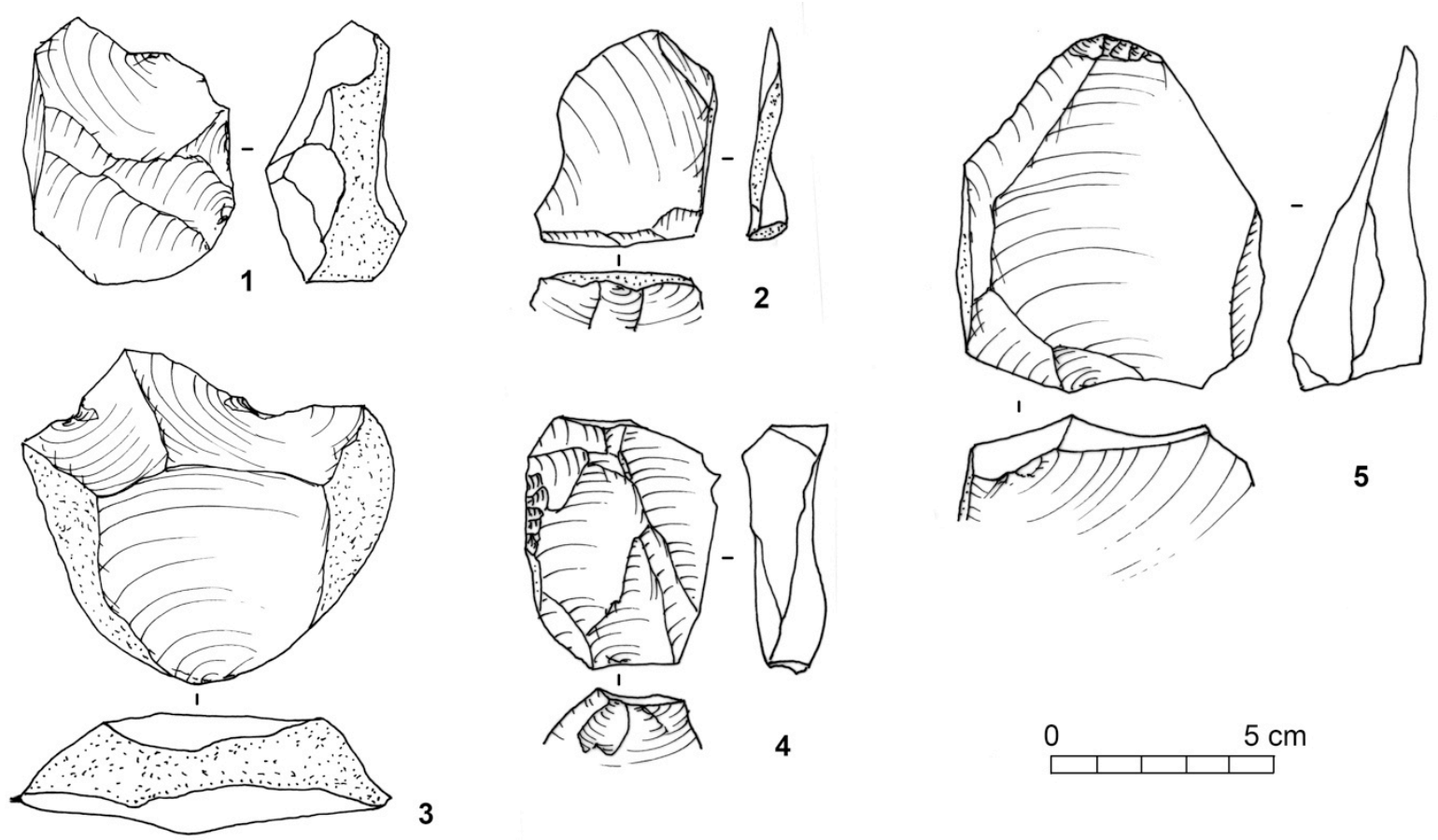

5

Figure 6. Flakes and flake tools from Square 1 of Tell Ghanem al-Ali. 1-2: part-cortex flakes; 3: retouched partcortex flake; 4-5: retouched flakes (1: topsoil; 2: Levels 1-3; 3: Level 6; 4: Level 8; 5: Level 7).

Although admittedly a simple one dealing only with a few basic technological attributes, the above analysis evidently demonstrates that Early Bronze Age lithic technology on the Middle Euphrates was never static. The diachronic changes, which have never been emphasised in the literature, can be summarised as follows. The technology of the earliest phase (Phase 1) at Tell Ghanem al-Ali was characterised by a combination of methods that used working-surface platforms and single-platform core reduction. This feature is in fact similar to what is known of the Late Chalcolithic period, as documented in the levels of Tell Kosak Shamali dating to the 4th millennium BCE (Nishiaki 2003). The similarity is not surprising, considering the chronological position of Phase 1. Some authors (e.g. Lebeau \& de Miroschedji 2011) regard this phase as the transitional period from the Chalcolithic to Early Bronze Age. On the other hand, the flake production in the latest phases (Phases 3 and 4) was in principle carried out using cortex-platform cores. The intermediate phase (Phase 2) can be regarded as transitional between these two technologically separable industries of the Early Bronze Age. The pattern implies that the technological change was a gradual process.

The background of these changes remains to be clarified in the future. The increasing popularity of cortex-platform technology must have been related to the higher demand of naturally backed flakes, probably butchering or cutting tools in domestic contexts (Greenfield 2006). Also worth considering is a possible link with the changing trend in raw material trade networks during the Early Bronze Age in northern Syria. The decline of single-platform core technology at settlements like Ghanem al-Ali, which required more preparation, might have resulted from the developing specialization in the production and distribution of large blades for farming, known as Canaanean blades. Such blades are believed to have been produced at specialist workshops near flint outcrops in Anatolia to the north and distributed to settlements on the northern Syrian steppe to the south. The distribution consisted of either finished products or prepared cores (Hertenberger et al. 2000; Nishiaki 2012). Canaanean blades appeared in small numbers in northern Syria during the Late Chalcolithic (Nishiaki 2003), but rapidly increased in the Early Bronze Age. Their main functional role was probably related to farming, although more work is needed to determine whether they represent sickle elements 
or threshing sledges (Chabot 2002). The replacement of locally manufactured blades or flakeblades by imported Canaanean blades must have caused significant consequences in the domestic core reduction technology. As a matter of fact, the absence of local flint tools with gloss indicates that local flint production was directed towards yielding somewhat domestic tools such as butchering knives and scrapers (Greenfield 2006, 2012). Unfortunately, however, the too rare occurrence of Canaanean blades and the lack of use-wear analysis on flint tools at Tell Ghanem al-Ali prevent us from evaluating these possibilities with stratigraphic evidence.

\section{Estimating the chronological positions of aceramic flint flake scatters}

The chronological scheme developed at Tell Ghanem al-Ali would help in dating the flint scatters frequently discovered on the steppe. Because potential chronological markers such as standardised tools (Table 5), architecture and pottery are absent, the configuration of stone reduction technology is nearly the only possible means of estimating their chronological positions. In my previous study (Nishiaki 2010b), the assemblage from one scatter at Shabout East (Loc. 20A), considered as most typical of the steppe scatters, was compared with the Early Bronze Age assemblage excavated from Square 1 of Tell Ghanem al-Ali. The strong similarity of these assemblages in the predominant production of naturally backed flakes led me to conclude that the steppe assemblages include those of the Early Bronze Age. According to the chronological scheme provided here, we can discuss its chronological position even more in detail. The aceramic assemblage of Shabout East can be compared to Phases 3 and 4 of Tell Ghanem al-Ali; more specifically, they are most similar to Phase 4 (ca. 2350-2050 cal $\mathrm{BCE})$.

Table 5. Retouched tools from Square 2 of Tell Ghanem al-Ali. Abbreviations: d: retouched on dorsal surface; v: retouched on ventral surface.

\begin{tabular}{lcccccccc}
\hline Major tool types & Topsoil & Levels 1-3 & Level 4 & Level 5 & Level 6 & Level 7 & Level 8 & Total \\
\hline Scraper (d) & $0(0.0)$ & $0(0.0)$ & $1(33.3)$ & $0(0.0)$ & $0(0.0)$ & $1(20.0)$ & $0(0.0)$ & $2(6.7)$ \\
Denticulate (d) & $1(50.0)$ & $0(0.0)$ & $1(33.3)$ & $0(0.0)$ & $1(12.5)$ & $1(20.0)$ & $1(50.0)$ & $5(16.7)$ \\
Denticulate (v) & $0(0.0)$ & $0(0.0)$ & $1(33.3)$ & $3(75.0)$ & $0(0.0)$ & $1(20.0)$ & $0(0.0)$ & $5(16.7)$ \\
Notch (d) & $0(0.0)$ & $0(0.0)$ & $0(0.0)$ & $0(0.0)$ & $2(25.0)$ & $0(0.0)$ & $0(0.0)$ & $2(6.7)$ \\
Notch (v) & $0(0.0)$ & $2(33.3)$ & $0(0.0)$ & $0(0.0)$ & $1(12.5)$ & $0(0.0)$ & $1(50.0)$ & $4(13.3)$ \\
Retouched flake (d) & $1(50.0)$ & $2(33.3)$ & $0(0.0)$ & $1(25.0)$ & $0(0.0)$ & $0(0.0)$ & $0(0.0)$ & $4(13.3)$ \\
Retouched flake (v) & $0(0.0)$ & $2(33.3)$ & $0(0.0)$ & $0(0.0)$ & $4(50.0)$ & $2(40.0)$ & $0(0.0)$ & $8(26.7)$ \\
\hline Total & $2(100.0)$ & $6(100.0)$ & $3(100.0)$ & $4(100.0)$ & $8(100.0)$ & $5(100.0)$ & $2(100.0)$ & $30(100.0)$ \\
\hline
\end{tabular}

Regarding the other examples, flint scatters have been identified at numerous localities in our survey area, numbering nearly 100 when small ones with less than ten flint artefacts are included (Nishiaki in press). If all of these were dated, we could discuss the temporal and spatial patterns in human use of the steppe in this region. An improved understanding of these patterns is much needed to verify the assumption that expansion into the steppe was developed in the third millennium BCE and later. In the meantime, a pilot study was attempted on the assemblages that have been studied to date using the same classification system applied to the Tell Ghanem al-Ali assemblages.

The samples were obtained at nine localities on the steppe. The sampling was made from a $5 \times 5 \mathrm{~m}$ square arbitrarily set up at each scatter except at Localities 24AA $(1 \times 1 \mathrm{~m})$ and 27AC $(3 \times 3 \mathrm{~m})$, where the denser distributions of flint artefacts were recorded. The nine localities include Loc. 23H, near the large cemetery of the early Middle Bronze Age (Nishiaki et al. 2009), from which three radiocarbon dates were obtained from looted holes, indicating the early second millennium BCE. In addition to these assemblages from our survey, Late 
Chalcolithic flake assemblages from layers of Tell Kosak Shamali dating to the 4th millennium BCE (Nishiaki 2003) are also included in the analysis to evaluate Bronze Age technological developments over a longer time period.

Due to the scarcity of cores in the study samples, analysis focused on the platform types for debitage (Table 6), which in fact closely reflect the core technology as well. A multivariate statistical technique, correspondence analysis, was conducted to examine the similarities and dissimilarities in platform types. The results (Figure 7) reveal an intriguing pattern. The platform types exhibit time-vectored changes through stages: the Late Chalcolithic, early phase of the Early Bronze Age, late phase of the Early Bronze Age and early Middle Bronze Age. The Late Chalcolithic assemblages from Tell Kosak Shamali (B1B6) comprise one group, characterised by the relatively common use of plain and dihedral platform types. The absence of our survey sites in this group, which will be remedied by future studies, corresponds with the lack of mound sites of this period in the lowlands. All three mounds recorded in the lowlands (Figure 1) belong to the Bronze Age. Human occupations in the study region might have indeed started in the Early Bronze Age. The second group, including three survey scatters (27AC, 27V and 9E), is plotted between the Late Chalcolithic and late Early Bronze Age groups. The flake platforms of this group are characterised by the moderate use of both plain and cortex platforms (Table 6). Given that the Phase 1 assemblage of Tell Ghanem al-Ali (TGA1) is included, this group is thought to represent the early phase of the Early Bronze Age. The third group is the largest which includes later phases of the Early Bronze Age sequence of Tell Ghanem al-Ali (TGA2-4). The assemblages are characterised by the heavy use of cortical (and cortical-plain) platforms for flake production. The last group is represented by only one assemblage, $23 \mathrm{H}$, which has been dated to the early Middle Bronze Age. The assemblage contains numerous flakes with shattered platforms.

Table 6. Platform types for debitage products from survey localities and related sites*. Abbreviations: LC: Late Chalcolithic; EBA: Early Bronze Age; MBA: Middle Bronze Age.

\begin{tabular}{|c|c|c|c|c|c|c|c|c|c|}
\hline Assemblages & Codes & Period & Cortical & $\begin{array}{l}\text { Cortical } \\
\text { + Plain }\end{array}$ & Plain & Shattered & Dihedral & Faceted & Total \\
\hline Kosak Shamali B1 & B1 & LC & 4 & 0 & 31 & 3 & 2 & 2 & 42 \\
\hline Kosak Shamali B2 & B2 & $\mathrm{LC}$ & 3 & 0 & 14 & 2 & 2 & 0 & 21 \\
\hline Kosak Shamali B3 & B3 & $\mathrm{LC}$ & 17 & 2 & 113 & 17 & 14 & 4 & 167 \\
\hline Kosak Shamali B4 & B4 & LC & 56 & 8 & 270 & 32 & 25 & 13 & 404 \\
\hline Kosak Shamali B5 & B5 & LC & 27 & 4 & 86 & 14 & 12 & 2 & 145 \\
\hline Kosak Shamali B6 & B6 & $\mathrm{LC}$ & 7 & 0 & 32 & 6 & 4 & 0 & 49 \\
\hline Ghanem al-Ali Phase 1 & TGA1 & EBA & 20 & 0 & 26 & 2 & 3 & 0 & 51 \\
\hline Ghanem al-Ali Phase 2 & TGA2 & EBA & 50 & 2 & 13 & 0 & 3 & 1 & 69 \\
\hline Ghanem al-Ali Phase 3 & TGA3 & EBA & 52 & 2 & 9 & 4 & 0 & 0 & 67 \\
\hline Ghanem al-Ali Phase 4 & TGA4 & EBA & 16 & 2 & 1 & 3 & 0 & 0 & 22 \\
\hline Ghanem al-Ali Square 1 & TGAsq1 & EBA & 482 & 12 & 23 & 39 & 2 & 0 & 558 \\
\hline Loc. 23H (Jazla) & $23 \mathrm{H}$ & MBA & 22 & 0 & 4 & 9 & 1 & 0 & 36 \\
\hline Loc. 9E & $9 \mathrm{E}$ & unknown & 6 & 0 & 10 & 0 & 0 & 0 & 16 \\
\hline Loc. 20A (Shabout East) & $20 \mathrm{~A}$ & unknown & 59 & 2 & 19 & 6 & 0 & 1 & 87 \\
\hline Loc. $24 \mathrm{AA}$ & $24 \mathrm{AA}$ & unknown & 77 & 3 & 28 & 4 & 7 & 2 & 121 \\
\hline Loc. 27AC & $27 \mathrm{AC}$ & unknown & 8 & 0 & 7 & 0 & 1 & 0 & 16 \\
\hline Loc. 27D & 27D & unknown & 21 & 2 & 6 & 3 & 4 & 1 & 37 \\
\hline Loc. $27 \mathrm{~V}$ & $27 \mathrm{~V}$ & unknown & 4 & 2 & 19 & 0 & 0 & 1 & 26 \\
\hline Loc. $28 \mathrm{~F}$ & $28 \mathrm{~F}$ & unknown & 46 & 3 & 26 & 13 & 2 & 1 & 91 \\
\hline Loc. 280 & 280 & unknown & 57 & 1 & 13 & 12 & 0 & 1 & 84 \\
\hline
\end{tabular}

*Broken flakes were omitted from analysis. 


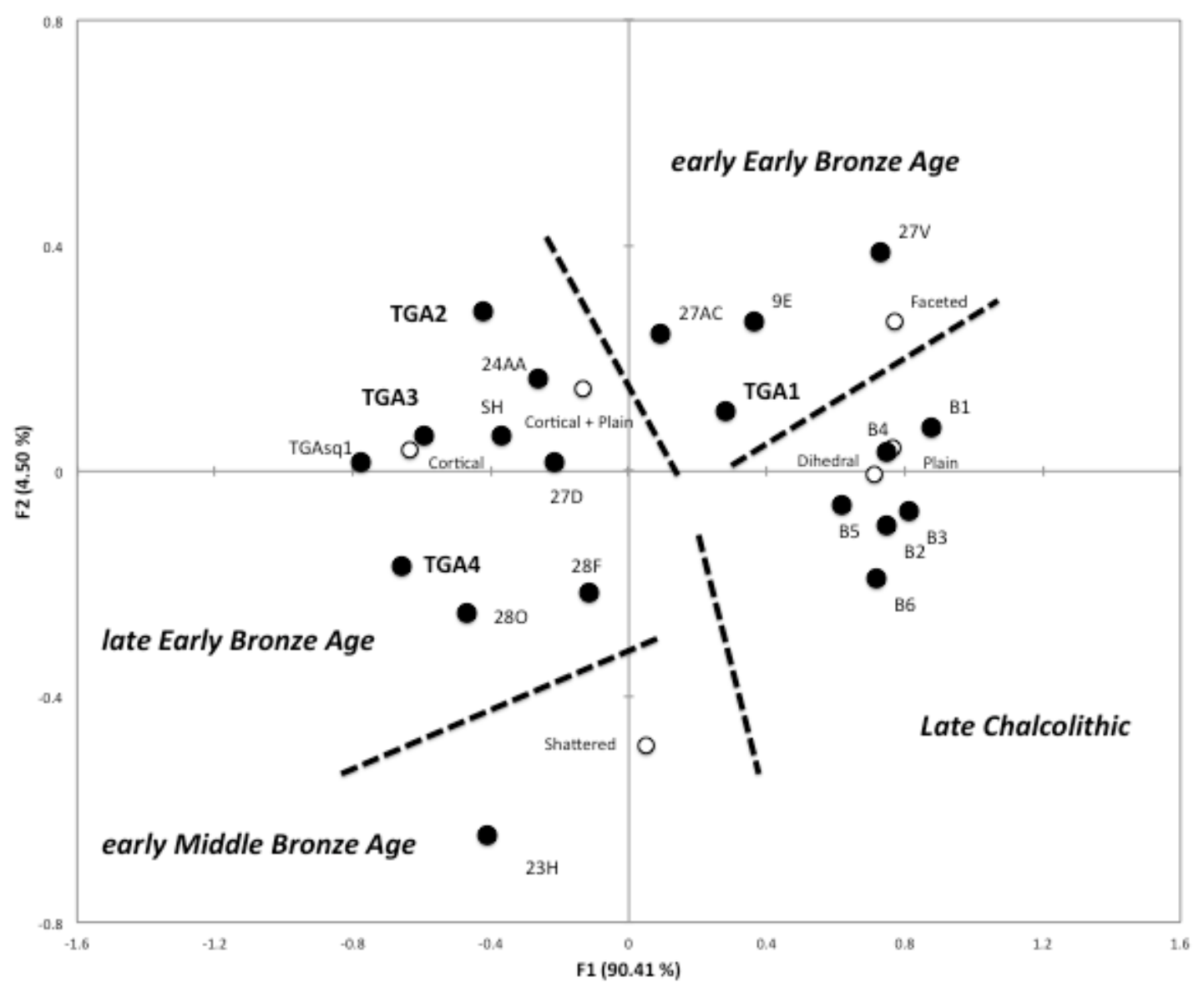

Figure 7. Results of a correspondence analysis of flake platform types from Tell Ghanem al-Ali and selected survey sites. For the legends, please see text.

While these results should be treated as experimental, the emerging pattern deserves close attention. Particularly interesting is that the dated assemblages (B1-6, TGA1-4 and 23H) are plotted in counter clockwise order in Figure 7, suggesting that the core-platform technology followed patterned diachronic changes. If taken at face value, the survey sites may indeed include a larger number of scatters from the late Early Bronze Age in the late third millennium BCE.

It is known that this time period on the Middle Euphrates witnessed much socioeconomic change (Cooper 2006). The third quarter of the millennium (Phase 3 of Tell Ghanem al-Ali) was characterised by an expansion of settlements and urban transformations, accompanied by the rise of impressive monuments, temples and fortifications (Cooper 2006: 15). In the last quarter (Phase 4), however, many settlements in the valley were either reduced or even abandoned, leaving only traces of sparse occupations. The evidence from Tell Ghanem al-Ali suggests that such changes occurred in our study area as well. Possible fortification structures and the extensive use of gypsum floors for buildings appeared for the first time in Phase 3 of Tell Ghanem al-Ali (Hasegawa 2010). The subsistence economy may also have changed in the same period. Botanical evidence from Tell Ghanem al-Ali indicates the incorporation of grape cultivation into farming that was previously dominated by barley (Akashi 2011). Subsequently, the nature of the settlement significantly changed in Phase 4 , for which no standing structures have been recovered thus far. Is the suggested increase in steppe exploitation a reflection of population increase in Phase 3, when livestock herding on the steppe might have intensified, or is it due to the shift in emphasis to a more nomadic way of life in Phase 4 ? The latter is an extremely interesting possibility, given that the first cuneiform 
records mentioning nomads on the Middle Euphrates appeared in this period (Postgate 1994). Although this question remains unanswered at this stage of research, the present study indicates the value of a proper understanding of lithic technology for defining the timing and processes of steppe exploitation by human groups.

\section{Conclusions}

This study examines how flake production technology at Tell Ghanem al-Ali changed over the course of the Early Bronze Age. It also attempts to estimate the dates of flint scatters on the steppe by comparing them to assemblages coming from secure stratigraphic contexts. This research finds that many of the steppe flint scatters might be dated to the later part of the third millennium BCE, particularly the last few centuries. The increase of scatters having distinctive technological features can be interpreted as evidence of the increasing use of the steppe at that time. Further inquiry into this phenomenon using other types of archaeological records and information from cuneiform texts should yield a better understanding of the dynamic socioeconomic processes that took place in this period.

Another implication of this study is that flake production technology of the Early Bronze Age did not comprise a single industry, as suggested by its current perception as banal or homogeneous. Instead, it showed recognizable temporal changes. The Chalcolithic-like technology at the beginning of the Early Bronze Age was gradually replaced by a technology specific to its later phase, which I have described as a cortex-platform technology. Future research should explore the reasons behind this change. Flake production technology, mostly implemented in domestic contexts, must have been related to different facets of society than those of the standardised, frequently traded lithic products such as Canaanean blades and tabular scrapers which have received much attention in current research on Early Bronze Age lithics (e.g. Rosen 1997; Chabot 2000; Caneva 1993). Flake technology and its resultant ad hoc tools must have played a far wider role in daily activities (Greenfield 2006, 2013), the analysis of which is indispensable to compensate the data from specialised tools. Likewise, understanding contexts of the learning process of this simple manufacturing technology would offer an important clue for defining the means of cultural transmission in domestic contexts of the Early Bronze Age. Although the present study emphasises the importance of understanding flake production technology as a chronological marker, the analytical possibility of discerning domestic technology should also be further explored.

\section{Acknowledgements}

My sincere thanks go to Dr. Bassam Jamous and Dr. Michel al-Maqdissi, who permitted me to conduct the fieldwork; and Prof. Katsuhiko Ohnuma and Mr. Ahmed Sultan, who granted me access to the lithic collection of Tell Ghanem al-Ali. I would like to thank Dr. Seiji Kadowaki, who prepared a satellite image in Figure 1. Mr. Atsunori Hasegawa provided me with stratigraphic information on the collection. The present study was supported in part by a grant from the Ministry of Culture, Education and Sports, Japan.

\section{References}

Akashi, C. 2011, The subsistence and the plant use in Tell Ghanem al-Ali: Early Bronze Age Syria. Al-Rafidan, 32: 105-110.

Algaze, G. 1999, Trends in the archaeological development of the Upper Euphrates basin of Southeastern Anatolia during the Late Chalcolithic and Early Bronze Ages. In: 
Archaeology of the Upper Syrian Euphrates, the Tishreen Dam Area, (Del Omo Lete, G. \& Montero Fenollos, J.-L., Eds.), Universitat de Barcelona, Barcelona: p. 535-572.

Al-Maqdissi, M. \& Ohnuma, K., (Eds.), 2009, Preliminary reports of the Syria-Japan archaeological joint research in the region of Ar-Raqqa, Syria, 2008. Al-Rafidan, 30: $135-225$.

Al-Maqdissi, M. \& Ohnuma, K., (Eds.), 2010, Preliminary reports of the Syria-Japan archaeological joint research in the region of Ar-Raqqa, Syria, 2009. Al-Rafidan, 31: 97-207.

Al-Maqdissi, M. \& Ohnuma, K., (Eds.), 2011, Preliminary reports of the Syria-Japan archaeological joint research in the region of Ar-Raqqa, Syria, 2010. Al-Rafidan, 32: 119-209.

Behm-Blancke, M.R. 1992, Hassek Höyük: Naturwissenschaftiche Untersuchungen und Lithische Industrie, Istanbuler Forschungen Vol. 38, Ernst Wasmuth Verlag, Tübingen, 294 p. (in German) (Hassek Höyük: scientific investigations and lithic industry)

Caneva, I. 1993, From Chalcolithic to Early Bronze Age III at Arslantepe: a lithic perspective. In: Between the Rivers and Over the Mountains, (Frangipane, M., Hauptmann, H., Liverani, M., Matthiae, P., \& Mellink, M., Eds.), Universita di Roma La Sapienza, Rome: p. 319-339.

Chabot, J. 2002, Tell ‘Atij, Tell Gudeda: Industrie Lithique. CELAT, Quebec, 226 p.

Conolly, J. 2003, Tools and debitage of obsidian and flint. In: Excavations at Tell Brak, Vol. 4, (Matthews, R., Ed.), British School of Archaeology in Iraq, London: p. 363-375.

Cooper, L. 2006, Early Urbanism on the Syrian Euphrates, Routledge, London, 313 p.

Falb, C., Krasnik, K., Meyer, J,-W. \& Vila, E. 2005, Gräber des 3. Jahrtausends v. Chr. im syrischen Euphrattal: 4. Der Friedhof von Abu Hamed, Schriften zur vorderasiatischen Archäologie Vol. 8, Saarländische Druckerei \& Verlag, Saarwellingen, 365 p. (in German) (Graves of the 3rd Millennium BC in the Syrian Euphrates Valley. 4 The cemetery of Abu Hamed)

Greenfield, H.J. 2006, Slicing cut marks on animal bones: diagnostics for identifying stone tool type and raw material. Journal of Field Archaeology, 31(2): 147-163. doi:10.1179/009346906791071972

Greenfield, H.J. 2013, The fall of the house of flint: a zooarchaeological perspective on the decline of chipped stone tools for butchering animals in the Bronze and Iron Ages of the Southern Levant. Lithic Technology, 38(3): 161-178. doi:10.1179/0197726113Z.00000000019

Hasegawa, A. 2010, Sondage at the site of Tell Ghanem al-Ali. Al-Rafidan, Special Issue: 2535.

Hunbury-Tenison, J. 1983, The 1982 flaked stone assemblage at Jebel Aruda, Syria. Akkadica, 33: 27-39.

Hertenberger, B., Rosen, S., \& Matney, T. 2000, The Early Bronze Age blade workshop at Titris Hoyuk. Near Eastern Archaeology 63(1): 51-58. doi:10.2307/3210808

Kohlmeyer, K. 1984, Euphrat-Survey: die mit mitteln der gerda henkel stiftung durchgeführte archäologische geländebegehung im Syrischen Euphrattal. Mitteilungen der Deutschen Orient-Gesellschaft zu Berlin, 116: 95-118. 
Kume, S. \& Sudo, H. 2010, 若手研究者が挑むセム系部族社会の形成一ユーフラテス河 中流域の青銅器時代考古学, Okayama Orient Museum, Okayama, 32 p. (in Japanese) ("Contributions of Young Researchers to Understanding of the Formation of Tribal Communities in the Bishri Mountains, the Middle Euphrates")

Lebeau, M. \& de Miroschedji, P. 2011, Associated Regional Chronologies for the Ancient Near East and the Eastern Mediterranean, Accessed: 01 March 2014. URL: http://www.arcane.uni-tuebingen.de/index.html

Lyonnet, B. 2009, Who lived in the third millennium "round cities" of northern Syria? In: Nomads, Tribes, and the State in the Ancient Near East, (Szuchman, J., Ed.), The Oriental Institute of the University of Chicago, Chicago: p. 179-200.

Meyer, J.-W. 2010, The cemetery of Abu Hamad: a burial place for pastoral groups? . AlRafidan, Special Issue: 155-163.

Nakamura, T. 2010, The Early Bronze Age chronology based on ${ }^{14} \mathrm{C}$ ages of charcoal remains from Tell Ghanem al-Ali. Al-Rafidan, Special Issue: 119-129.

Nishiaki, Y. 2003, Chronological developments of the Chalcolithic flaked stone industries at Tell Kosak Shamali. In: Tell Kosak Shamali - The Archaeological Investigations on the Upper Euphrates, Syria. Volume 2: Chalcolithic Technology and Subsistence, (Nishiaki, Y. \& Matsutani, T., Eds.), Oxbow Books, Oxford: p. 15-111.

Nishiaki, Y. 2010a, Archaeological evidence of the Early Bronze Age communities in the Middle Euphrates steppe, North Syria. Al-Rafidan, Special Issue: 37-48.

Nishiaki, Y. 2010b, Early Bronze Age flint technology and flake scatters in the North Syrian steppe along the Middle Euphrates. Levant, 42(2): 170-184. doi:10.1179/175638010X12797237885730

Nishiaki, Y. 2012. Notes on the third millennium blades from Tell Abu Hujeira. In: Trois Campagnes de Fouilles Syriennes à Tell Abu Hujeira, Hasseke (1988-1990): Cinquieme et Sixieme Parties, (Suleiman, A. \& Quenet, P., Eds.), Documents d'Archéologie Syrienne Vol. 17, Directorate-General of Antiquities and Museums, Damascus: p. 6370 .

Nishiaki, Y. (in press), Steppe exploitation by Bronze Age communities in the Middle Euphrates Valley, Syria. In: Settlement Dynamics and Human-Landscape Interaction in the Steppes and Deserts of Syria, (Morandi Bonacossi, D., Ed.), Studia Chaburensia, Otto Harrassowitz, Wiesbaden.

Nishiaki, Y., Kadowaki, S., \& Kume, S. 2009, Archaeological survey around Tell Ghanem Al-Ali. Al-Rafidan, 30: 145-153, 160-163.

Nishiaki, Y. \& Abe, M. 2010, Archaeological survey around Tell Ghanem Al-Ali (III). AlRafidan, 31: 125-128.

Nishiaki, Y., Abe, M., Kadowaki, S., Kume, S., \& Nakata, H. 2011a, Archaeological survey around Tell Ghanem Al-Ali (II). Al-Rafidan, 32: 189-215.

Nishiaki, Y., Kadowaki, S., Nakata, H., Shimogama, K., \& Hayakawa, Y. 2011b, Archaeological survey around Tell Gahnem Al-Ali (IV). Al-Rafidan, 32: 125-133.

Nishiaki, Y., Kadowaki, S., Kume, S., \& Shimogama, K. (2012) Archaeological survey around Tell Gahnem Al-‘Ali (V). Al-Rafidan, 33: 1-6. 
Peltenburg, E. J. 2007, Euphrates River Valley Settlement: The Carchemish Sector in the Third Millennium BC, Levant supplementary series Vol. 5, Oxbow Books, Oxford, 285 p.

Peltenburg, E. J. 2008, Enclosing the ancestors and the growth of socio-political complexity in Early Bronze Age in Syria. Scienze Dell'antichita, Storia Archeologia Antropologia, 14(1): 215-247.

Porter, A. 2002, The dynamics of death: Ancestors, pastoralism, and the origins of a thirdmillennium city in Syria. Bulletin of the American Schools of Oriental Research, 325: 136. doi: $10.2307 / 1357712$

Porter, A. 2007, The ceramic assemblages of the third millennium in the Euphrates region. In: Céramique de l'âge du bronze en Syrie II, L'Euphrates et la region de Jézireh, (AlMaqdissi, M., Matoian, V., \& Christophe, C., Eds.), IFAPO, Beyrouth: p. 3-21.

Porter, A. 2008, Evocative topography: Experience, time, and politics in a landscape of death. Scienze Dell'antichita, Storia Archeologia Antropologia, 14(1): 195-214.

Postgate, J.N. 1994, Early Mesopotamia: Society and Economy at the Dawn of History (2nd ed.), Routledge, London and New York, 367 p.

Rosen, S. A. 1997, Lithics After the Stone Age: A Handbook of Stone Tools from the Levant, Altamira Press, Walnut Creek, 184 p.

Schmidt K. 1996, Norsuntepe, Kleinfunde I: Die Lithische Industrie, Archaeologica Euphratica Vol. 1, Verlag Philipp von Zabern, Mainz am Rhein, 305 p.

Westaway, R., Bridgland, D., Daoud, M., Radwan, Y., Abu Romieh, M., Yassminh, R., \& AlAshkar, A. 2007, Investigations of Euphrates terraces and related archaeology, NE Syria, 2006-2007. CBRL Bulletin, 2007(2): 82-89.

Wilkinson, T. J. 2004, On the Margin of the Euphrates: Settlement and Land Use at Tell esSweyhat and in the Upper Lake Assad Area, Syria, The Oriental Institute Publications Vol. 124, The Oriental Institute of the University of Chicago, Chicago, 292 p. 